\title{
Viral Research in Brazilian Owls (Tyto alba and Rhinoptynx clamator) by Transmission Electron Microscopy
}

\author{
Investigación Viral en Buhos Brasileños (Tyto alba y Rhinoptynx clamator) \\ a través de Microscopía Electrónica de Transmisión
}

\author{
"Catroxo, M. H. B.; "Taniguchi, D. L.; "Melo, N. A.; **Milanelo, L.; \\ ${ }^{* * *}$ Petrella, S.; **Alves, M.; "Martins, A. M. C. R. P. F. \& *Rebouças, M. M.
}

CATROXO, M. H. B.; TANIGUChI, D. L.; MELO, N. A.; MILANELO, L.; PETRELlA, S.; ALVES, M.; MARTINS, A. M. C. P. F. \& REBOUÇAS, M. M. Viral research in Brazilian owls (Tyto alba and Rhinoptynx clamator) by transmission electron microscopy. Int. J. Morphol., 28(2):627-636, 2010.

SUMMARY: The barn-owl (Tyto Alba) and striped-owl (Rhinoptynx clamator) belong respectively to the families Tytonidae and Strigidae. Avian paramyxoviruses have been isolated from a variety of species of wild and domestic birds wordlwide causing diverse clinical symptoms and signs. Paramyxoviruses belong to the family Paramyxoviridae and Avulovirus genus, including nine serotypes (APMV 1 to 9). The lymphoid leukosis is a retrovirus-induced neoplasia. The avian retroviruses belong to the Retroviridae family and to the Alpharetrovirus genus. Coronaviruses can cause respiratory and enteric disease in several species of birds. They belong to the Coronaviridae family and to the groups $3 \mathrm{a}$ e $3 \mathrm{c}$. In this study, we describe the presence of viruses in four owls, two barn owls (Tyto alba) and two striped owls (Rhinoptynx clamator), rescued from tree-lined streets of Sao Paulo, Brazil and sent to the Recovery Center of Wild Animals of the Tietê Ecological Park, where the animals died. Fragments of lung, liver and small intestine of these birds were processed for transmission electron microscopy utilizing negative staining (rapid preparation), immunoelectron microscopy and immunocitochemistry techniques. Under the transmission electron microscopy paramyxovirus particles, pleomorphic, roughly spherical or filamentous, measuring 100 to $500 \mathrm{~nm}$ of diameter containing an envelope covered by spikes, an herring-bone helical nucleocapsidlike structure, measuring 15 to $20 \mathrm{~nm}$ in diameter, were visualized in the samples of lung, liver and small intestine of all owls. In small intestine samples of the two striped-owl (owls 3 and 4) it was detected pleomorphic coronavirus particles with a diameter of 75-160 nm containing a solar corona-shaped envelope, with projections of approximately $20 \mathrm{~nm}$ of diameter. In liver fragments of one striped-owl (owl 4) pleomorphic particles of retrovirus with a diameter of 80-145 nm containing an envelope with short projections and diameter of $9 \mathrm{~nm}$ were observed. The presence of aggregates formed by antigen-antibody interaction, characterized the positive result obtained during the immunoelectron microscopy technique for paramyxovirus, retrovirus and coronavirus. In the immunocytochemistry technique, the antigen-antibody interaction was strongly enhanced by the dense colloidal gold particles over these viruses.

KEYWORDS: Paramyxovirus; Coronavirus; Retrovirus; Owls; Transmission electron microscopy.

\section{INTRODUCTION}

The barn owl (Tyto alba) and striped owl (Rhinoptynx clamator) species of the order Strigiformes respectively belong to families Tytonidae and Strigidae. They are nocturnal and carnivorous birds of prey, found throughout the Brazilian territory (Sick, 1997). They have been significant in the control of rodent populations for years. Their sensitivity to environmental changes in relation to the other animals in the food chain provides clues about the state of environmental conservation (Motta-Junior \& Albo, 2000).
Avian paramyxoviruses have been isolated from a variety of species of wild and domestic birds worldwide (Leeuw \& Peeters 1999). These viruses belong to the Mononegavirales order, Paramyxoviridae family. Paramyxovirinae subfamily and Avulavirus genus that include nine serotypes (APMV 1 to 9) and Pneumovirus genus include Avian Metapneumovirus. Paramyxoviruses are pleomorphic, enveloped containing a negative-sense, simple stranded RNA genome (Lamb \& Parks, 2007).

* Laboratory of Electron Microscopy, Biological Institute of São Paulo, SP, Brazil.

** Tiete Ecological Park, São Paulo, SP, Brazil

*** Adolfo Lutz Institute, São Paulo, SP, Brazil 
The Newcastle disease, caused by paramyxovirus APMV-1 type and highly pathogenic, is one of main diseases affecting the poultry trade. In worldwide economy it can be extremely harmful, producing considerable impact on the poultry industry (Jorgensen et al., 1998).

Psittacidae, passerines and pigeons, although more resistant to this disease, may present diverse clinical signs that include, depression, diarrhea, anorexia, ruffled feathers, conjunctivitis, dispnea, ataxia, tremors, paralysis and death (Richie \& Carter, 1995). In several species of owls in the wild or in captivity, the serotype APMV1 was found (Telbis et al., 1989, Lou et al. 1999; Hoffle et al., 2002; Oliveira Jr. et al., 2003; Schettler et al., 2003, Choi et al., 2008) and in other species of wild birds the serotypes APMV 2, 3, 5 were detected (Mustaffa-Babjee, 1974; Nerome et al., 1978; Gougjh et al., 1993, Ritchie et al., 1994; Shihmanter et al., 1998; Beck et al., 2003; Zhang et al., 2006; Jung et al., 2009).

In lymphoid leukosis, caused by retrovirus, neoplastic nodules may develop in the viscera and skin tissue of birds (Harrison \& Harrison 1986; Martins \& Catroxo, 2009) with a predominance in liver and spleen (Wadsworth et al., 1981; Fowler).

This neoplasm can reach several species of birds. Broilers and laying hens are affected more often, although turkeys and quail are also susceptible. Cases of lymphoid leukosis of passerines and galliform species were also reported (Nobel, 1972; Palmer \& Stauber, 1981; Wadsworth et al.; Loupal, 1984; Martins et al., 2004; Pongiluppi et al.; 2006; Hatai et al., 2008).

The clinical manifestation is variable and many times the affected birds are found dead without prior clinical manifestation (Wadsworth et al.; Fowler). Contamination might occur through vertical or horizontal transmission (Ritchie \& Cartier, 1995; Fadly, 1997). Studies show that wild birds that harbor the virus can spread it to areas around poultry farms (Varejka \& Tomsik, 1974).

Retroviruses are classified into seven designated genus Alpha, Beta, Gamma, Delta, Epsilon retroviruses, Spumavirus and Lentiviruses (Van Regenmortel et al., 2000). Alpha retroviruses ( $A L V$ genus) comprise the only genus confined to birds. The ALV members are classified into 10 subgroups (termed A-J) based on their host range, cross neutralization and viral interference (Coffin, 1992). The first four subgroups represent exogenous viruses of chickens, the subgroup E includes a family of endogenous chicken viruses and subgroup $\mathrm{F}$ and $\mathrm{G}$ include endogenous viruses of pheasants (Goff, 2007).
Coronavirus infects mainly birds of all ages. It is relevant in the poultry Industry and may cause respiratory and enteric disease in chickens with losses in its production and egg quality in nature hens (Worthington et al., 2008). Wild birds may play a role as both reservoirs, and as the long distance vectors of infectious bronchitis and other coronaviruses (Hughes et al., 2009).

This virus was detected in wild birds species (Catroxo et al., 1996, 2000; Pongiluppi et al., 2004; Jonassen et al., 2005; Woo et al., 2008). Infectious bronchitis is one of the major diseases caused by coronavirus that compromises commercial poultry (Cavanagh \& Nagi, 1997; Pennycott, 2000; Guy et al., 1997; Circella et al.; 2007; Pohuang et al., 2009).

Coronaviruses are large enveloped positive-strand RNA. They have a round structure that is often 100 to $160 \mathrm{~nm}$ in diameter with distinctive long, petal-shaped spikes on the surface (Fenner et al., 1992). Avian coronaviruses belong to the Nidavirales order, Coronaviridae family and to the $3 \mathrm{a}$ and 3c groups (Wood et al., 2009). In emergency situations the transmission electron microscopy utilizing negative staining technique is an important tool to identify viruses, due to its speed and its ability to view multiple viral agents (Hazelton \& Gelderblom, 2003; Harris et al., 2006).

Considering the lack of literature concerning viruses in Brazilian owls, we have decided by the technique of transmission electron microscopy, to observe the possible presence of viral particles in organ fragments in barn owls (Tyto alba) and striped owls (Rhinoptynx clamator).

\section{MATERIAL AND METHOD}

Description of the cases.From November 2005 to May 2006, four owls (two barn-owls and two striped-owls) were rescued from tree-lined streets, in the city of São Paulo, SP, and sent to the Center of Recovery of Wild Animals of the Tietê Ecological Park, where they died. Next, they were sent to the Laboratory of Electron Microscopy, Biological Institute of São Paulo, to search for viral agents. During the necropsy, fragments were collected from lung, liver and small intestine of all owls. Later, these fragments were processed for transmission electron microscopy utilizing negative staining (rapid preparation), immunoelectron microscopy and immunocytochemistry techniques.

Negative staining technique (rapid preparation). In negative staining technique, fragments of lung, liver and small intestine were suspended in phosphate buffer $0.1 \mathrm{M}, \mathrm{pH}$ 
7.0. Drops of the suspensions were placed in contact with metallic copper grids, stabilized with carbon supporting film of $0.5 \%$ in collodium amyl acetate. Next, the grids were drained with filter paper and negatively stained at $2 \%$ ammonium molybdate, pH 5.0 (Brenner \& Horne, 1959; Hayat \& Miller, 1990; Madeley, 1997.

Immunoelectron microscopy technique. In this technique, copper grids, previously prepared with collodion film and stabilized with carbon were first incubated with protein $A(1 \mu \mathrm{l} / \mathrm{ml})$, placed in contact with a virus-specific antibody. After this, the grids were washed in PBS drops, incubated with the antigen, washed with drops of water and negatively stained with $2 \%$ ammonium molybdate, $\mathrm{pH}$ 5.0 (Almeida \& Waterson, 1969; Derrick, 1973; Berthiaume et al., 1981).

Immunocytochemistry Technique. At the immunolabeling technique with colloidal gold particles for negative staining, the copper grids were placed in contact with viral suspension and, after removing excess with filter paper, the same were put on specific primary antibody drops. After successive washings in PBS drops, the grids were incubated in protein A drops, in association with $10 \mathrm{~nm}$ colloidal gold particles (secondary antibody). Grids were then contrasted at $2 \%$ ammonium molybdate, pH 5.0 (Knutton, 1995).
All grids submitted to the reactions above described were observed in a Philips EM 208 electron microscope, at $80 \mathrm{kV}$.

\section{RESULTS}

Necropsy. During the necropsy, one barn owl (owl 1) had intestinal bleeding and the other (owl 2) showed bleeding in all organs. The striped owl (owl 3) presented lungs with whitish and autolysate areas of the liver. The presence of the small intestine, containing yellow and watery stools was also observed. In the striped owl (owl 4) it was observed the presence of hemorrhagic lungs, liver and small intestine with watery contents and also yellowish (Table I).

Negative staining technique (rapid preparation). Under the transmission electron microscopy paramyxovirus particles, pleomorphic, roughly spherical or filamentous, measuring 100 to $500 \mathrm{~nm}$ of diameter containing an envelope covered by spikes, with characteristic helical herring-bonelike nucleocapsid, measuring 15 to $20 \mathrm{~nm}$ in diameter, were visualized in the samples of lung, liver and small intestine of all owls (Fig. 1).

Table I. Description of samples according to the species, sex, age, necropsy results and transmission electron microscopy results.

\begin{tabular}{|c|c|c|c|c|c|c|}
\hline Identification & Species & Sexo & Age & Organ & Necropsy results & $\begin{array}{l}\text { Transmission } \\
\text { electron microscopy } \\
\text { results }\end{array}$ \\
\hline \multirow{3}{*}{1} & \multirow{3}{*}{ Barn owl } & \multirow{3}{*}{ Undetermined } & \multirow{3}{*}{ Adult } & Lung & No evidence of alteration & Paramy xovirus \\
\hline & & & & Liver & No evidence of alteration & Paramy xovirus \\
\hline & & & & Small intestine & Hemorrhagic & Paramy xovirus \\
\hline \multirow{3}{*}{2} & \multirow{3}{*}{ Barn owl } & \multirow{3}{*}{ Female } & \multirow{3}{*}{ Adul } & Lung & Hemorrhagic & Paramy xovirus \\
\hline & & & & Liver & Hemorrhagic & Paramy xovirus \\
\hline & & & & Small intestine & Hemorrhagic & Paramy xovirus \\
\hline \multirow{3}{*}{3} & \multirow{3}{*}{ Striped-owl } & \multirow{3}{*}{ Male } & \multirow{3}{*}{ Adul } & Lung & Whitish & Paramy xovirus \\
\hline & & & & Live & Autolysed areas & Paramy xovirus \\
\hline & & & & Small intestine & $\begin{array}{l}\text { Watery and yellowish } \\
\text { feces }\end{array}$ & $\begin{array}{l}\text { Paramy xovirus } \\
\text { Coronavirus }\end{array}$ \\
\hline \multirow{3}{*}{4} & \multirow{3}{*}{ Striped-owl } & \multirow{3}{*}{ Female } & \multirow{3}{*}{ Adul } & Lun & Hemorrhagic & Paramy xovirus \\
\hline & & & & Liver & Hemorrhagic & Paramy xovirus and \\
\hline & & & & Small intestine & $\begin{array}{l}\text { Watery and yellowish } \\
\text { feces }\end{array}$ & $\begin{array}{l}\text { Paramy xovirus, } \\
\text { Coronavirus }\end{array}$ \\
\hline
\end{tabular}


In liver and small intestine fragments of one stripedowl (owl 4) pleomorphic particles of retrovirus with a diameter of 80-145 $\mathrm{nm}$ and an envelope containing short projections with a diameter of $9 \mathrm{~nm}$ (Fig. 2) were observed.

In two small intestine samples of two striped-owls (owls 3 and 4) it was detected pleomorphic coronavirus

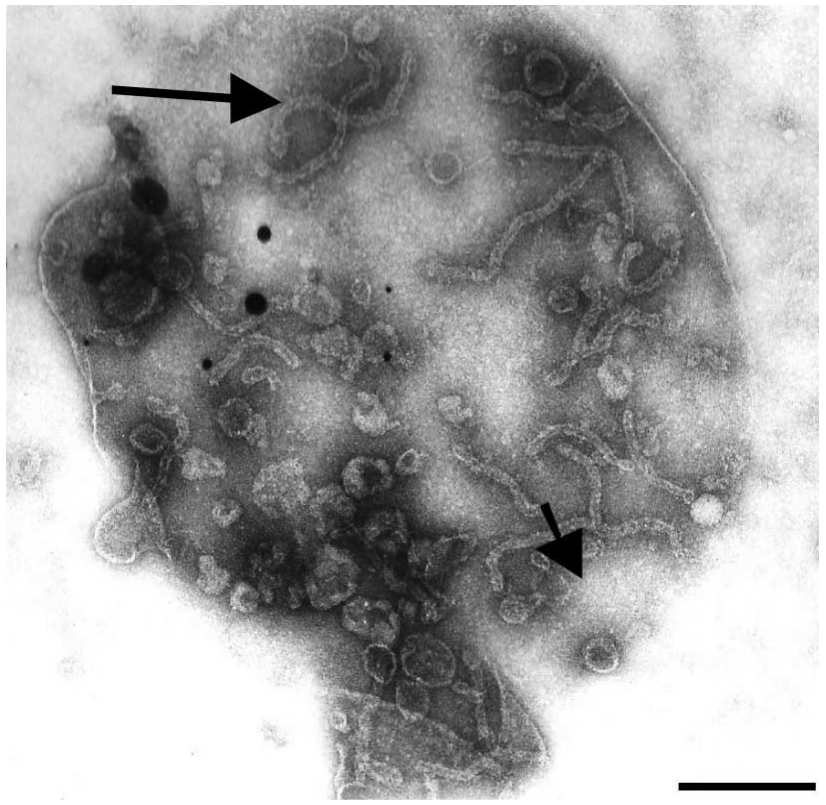

Fig. 1. Negatively stained paramyxovirus particles, pleomorphic, roughly spherical (minor arrow) or filamentous (big arrow), containing an envelope covered by spikes, with characteristic helical herring-bone-like nucleocapsid. Bar: $320 \mathrm{~nm}$.

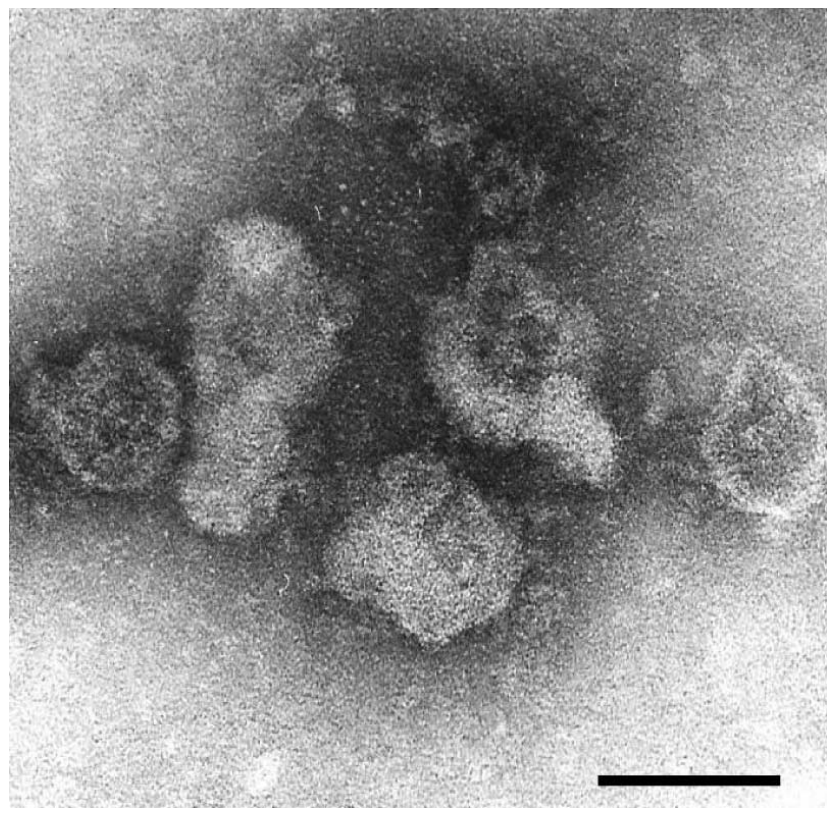

Fig. 2. Negatively stained pleomorphic retrovirus particles with an envelope containing short projections. Bar: $110 \mathrm{~nm}$. particles with a diameter of 75-160 nm containing a solar corona-shaped envelope, with projections of approximately $20 \mathrm{~nm}$ of diameter (Fig. 3).

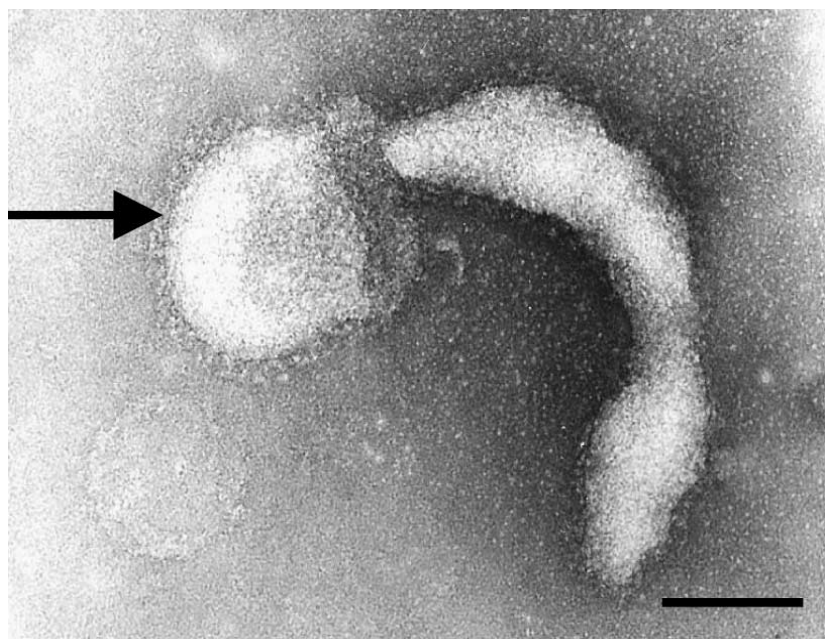

Fig. 3. Negatively stained pleomorphic coronavirus particles, with a solar corona-shaped envelope. Bar: $120 \mathrm{~nm}$.

Imunoelectron microscopy Technique. The presence of aggregates formed by antigen-antibody interaction, characterized the positive result obtained, at the immunoelectron microscopy technique for paramyxovirus (Fig. 4), retrovirus (Fig. 5) and coronavirus (Fig.6).

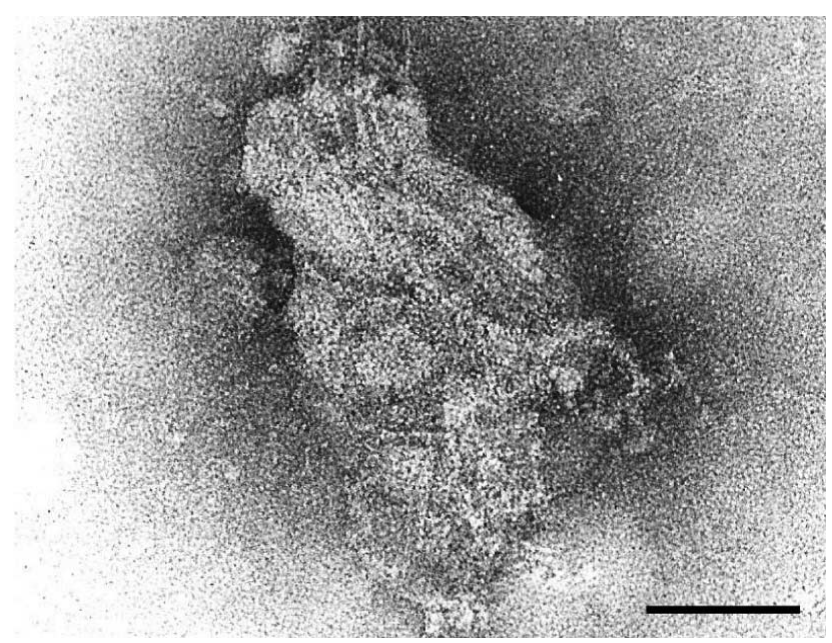

Fig. 4. In the immunoelectron microscopy technique the paramyxoviruses particles were aggregated by antigen-antibody interaction. Bar: $70 \mathrm{~nm}$.

Immunocytochemistry Technique. In the immunocytochemistry technique, the antigen-antibody interaction was strongly enhanced by the dense colloidal gold particles over the paramyxovirus (Fig.7), retrovirus (Fig. 8) and coronavirus particles (Fig. 9). 


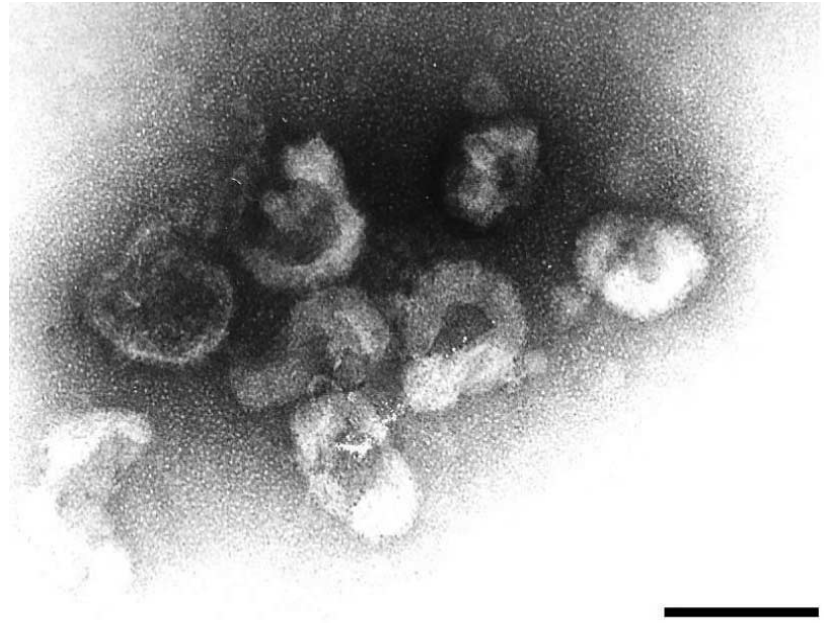

Fig. 5. Retroviruses particles aggregated by antigen-antibody interaction. Bar: $120 \mathrm{~nm}$.

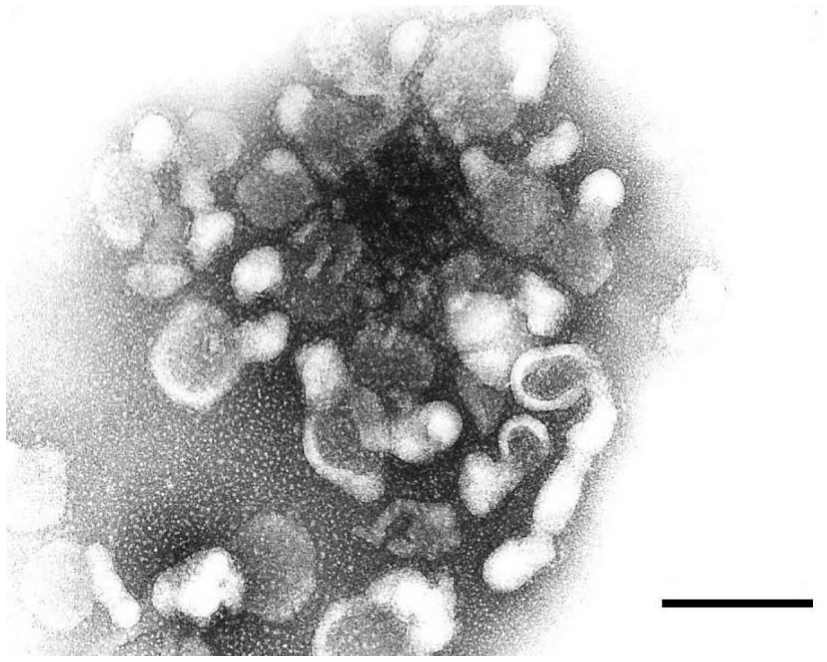

Fig. 6. Coronaviruses particles aggregated by antigen-antibody interaction. Bar: $200 \mathrm{~nm}$.

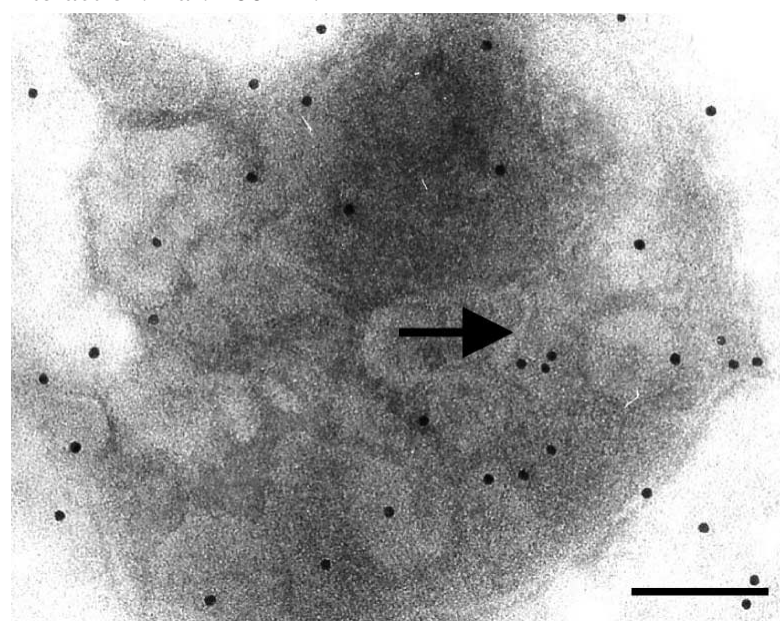

Fig. 7. In the immunocytochemistry technique, the antigen-antibody interaction was strongly enhanced by the dense colloidal gold particles (arrow) over the paramyxovirus particles. Bar: $140 \mathrm{~nm}$.

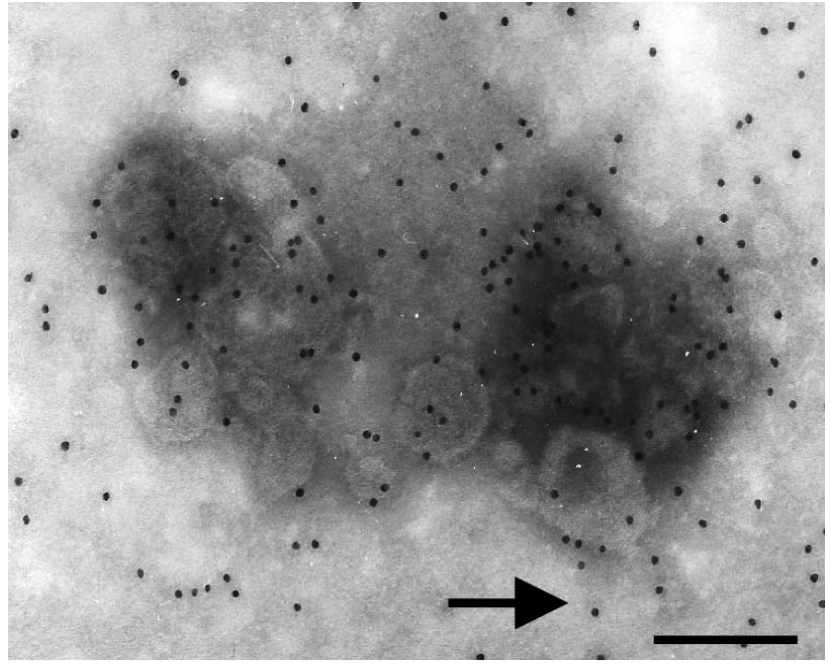

Fig. 8. Retroviruses particles strongly enhanced by colloidal gold particles (arrow). Bar: $180 \mathrm{~nm}$.

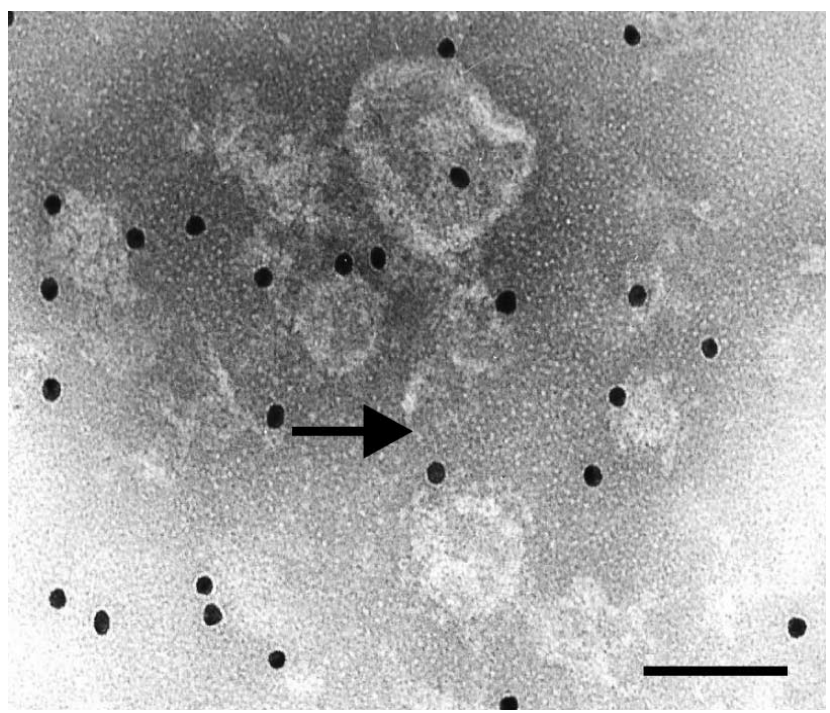

Fig. 9. Coronaviruses particles strongly enhanced by colloidal gold particles (arrow).Bar: $100 \mathrm{~nm}$.

\section{DISCUSSION}

In this study by means of the negative staining technique, viral particles with morphology similar to paramyxovirus were identified in suspensions of fragments of lung, liver and small intestine of two barn-owls (Tyto Alba) and two striped owls (Rhinoptynx clamator).

Other experiments using serological and molecular tests detected paramyxovirus APMV type 1 in several species of wild and captive owls (Telbis et al.; Gohm et al., 1999; Höffle et al.; Oliveira Junior et al.; Schettler et al.; Choi et al.). 
APMV 1, 2, 3, 5 types occur more often among freeliving birds, showing variable symptoms or remaining asymptomatic (Shihmanter et al.; Grund et al., 2002; Beck et al.; Greenacre, 200; Zhang et al.; Jung et al.).

Other researchers failed to detect paramyxovirus in owls (Catroxo et al., 2000; Shin et al., 2000; Sousa et al., 2010).

At least, 236 species of birds are susceptible to the paramyxovirus (Kaleta \& Baldhauf, 1988), and the wild birds are an important reservoir and disseminator (Oliveira Júnior).

The owls in our study had no symptoms or clinical signs of the disease. This asymptomatic state was also reported by other authors in poultry research. (Gohm et al.; Hoffle et al.; Oliveira Júnior et al.; Schettler et al.).

The intestinal hemorrhage was a common finding in the animals autopsied. This change characterizes the Newcastle as viscerotropic disease (Alexander, 2003).

Other types of paramyxoviruses (APMV 1, 2, 3 and 5 ) occur more frequently among birds in the wild, at times causing varied clinical symptoms (Shihmanter et al.; Grund et al.; Beck et al.; Greenacre; Zhang et al.; Jung et al.).

The morphological paramyxoviruses characteristics described by us were similar to those found in owls by Kou et al. and in other birds species (Gough et al., 1983, 1993; Catroxo et al., 2000; Chang et al., 2001; Grund et al., Zhang et al.).

By agglutination of a great number of paramyxovirus particles during the reaction of immunoelectron microscopy, we confirmed the presence of this virus in animals. The same technique was employed by Catroxo et al. (2003) who confirmed it in canine distemper.

Likewise, in the immunocytochemistry technique, the paramyxoviruses were sharply marked by colloidal gold particles. In previous studies, the use of this technique allowed the observation of avianpox (Catroxo et al., 2009).

The use of negative staining technique also helped in the discovery of coronavirus in samples of small intestine of two striped-owls (owls 3 and 4). During necropsy of these animals, the feces were watery and yellowish, giving evidence of diarrhea.

Some studies do not reported the existence of coronaviruses in other species of owls, such as burrowing owl (Speotyto cunicularia), tropical screech-owl (Otus owl) and barn owl (Tyto alba), but it was found in peregrine-falcon (Falco peregrinus ) (Catroxo et al., 2000; Pongiluppi et al., 2004; Sousa et al.).

During diarrhea outbreaks, coronavirus can be detected in species such as, rhea (Catroxo et al., 1996), turkey (Guy et al.; Breslin et al., 1999), quail (Circella et al.) and in pheasant (Gough et al., 1996; Pennycott), peacock (Liu et al., 2005), pigeon (Jonassen et al.) and psitacids (Gough et al., 2006) with concomitant respiratory problems.

The negative staining technique allowed us to observe viral particles with coronavirus features. Many authors have described similar particles by the same technique in birds (Dea et al., 1990; Catroxo et al., 1996, 2000; Pongiluppi et al., 2004; Liu et al.; Gough et al.; Circella et al., 2007).

In this study, positiveness was obtained by the immunomicroscopy method and sharp marking of this antigen with colloidal gold particles. Other authors confirmed the presence of coronavirus in birds using these techniques. (Dea \& Tijssen, 1989; Dea \& Garzon, 1991; Gough et al., 2006).

The presence of infectious bronchitis virus in wild and exotic birds can be explained by the interaction between species or by its close proximity with commercial poultry farms (Sousa et al.). Among all hosts, the diversity of coronaviruses is more evident in bats and poultry, as a result of species diversity, ability to fly, environmental pressure and habits of roosting and flocking (Woo et al., 2009).

In addition to paramyxovirus and coronavirus particles, the retrovirus was found in samples of liver and small intestine of one striped-owl (owl 4). The literature reports early findings of this virus in the small intestine of pale-breasted thrush (Turdus leucomelas) (Catroxo et al., 2006;), in nodules of gizzard ruddy ground-dove (Columbina talpacoti) (Pongiluppi et al., 2006) and roller canaries (Serinus canarius) (Martins et al.).

The retrovirus was observed in cases of lymphoid leukosis in wild bird columbiformes, psittaciformes and passerines (Nobel; Palmer \& Stauber, Wadsworth et al.; Loupl; Martins et al.; Catroxo et al., 2006; Pongiluppi et al., 2006). Free-living birds as the house sparrow (Passer domesticus) may harbor the leukosis virus, acting as disseminators especially in areas near poultry farms (Varejka \& Tomsik).

Although in this disease, nodules may develop in any visceral area or skin of the animal (Harrison \& Harrison), we did not check the presence of these in the organs examined from the two striped-owls (owls 3 and 4). 
A published article reported the presence of nodules in the gizzard of ruddy ground-dove (Columbina talpacoti) (Pongiluppi et al., 2006).

Although the four owl died without preliminary presentation of clinical signs, according to Wadsworth et al. the manifestation of these signs is variable and many times the affected birds are found dead without prior disclosure of clinical disease .

The positive results we obtained from the reaction of immunoelectron microscopy for retrovirus was signaled by the presence of aggregates formed by antigen-antibody interaction. Valicek et al. (1985) applying this technique observed retrovirus particles in enzootic bovine.

These retroviruses were also intensely labeled by colloidal gold, when we applied the immunocytochemistry method, also used to detect porcine endogenous retroviruses (Fischer et al., 2003).

The techniques used allow a quick visualization of viral particles. They are extremely effective in routine diagnosis of several avian viral pathogens. Additionally, it is worth emphasizing that the negative staining technique is one of the tests required by the OIE for the diagnosis of avian infectious bronchitis virus (OIE, 2008).

The accurate knowledge of viral diseases affecting birds of prey is of great importance, since some species, like the falcon peregrinus are constantly threatened by these viruses (Sander, 1995; Schettler et al.).

Owls deserve special attention in their preservation, their importance in the environment is vital, as is their cultural significance. (Sick, 1997).

CATroXo, M. H. B.; TANigUChI, D. L.; MELO, N. A.; MILANElO, L.; PETRELla, S.; ALVES, M.; MARTINS, A. M. C. P. F. \& REBOUÇAS, M. M. Investigación viral en buhos brasileños (Tyto alba y Rhinoptynx clamator) através de microscopía electrónica de transmisión. Int. J. Morphol., 28(2):627-636, 2010.

RESUMEN: La lechuza (Tyto Alba) y el búho de orejas (Rhinoptynx clamator) pertenecen respectivamente a las familias Strigidae y Tytonidae. El paramixovirus aviario se ha aislado de especies de vida silveste como las aves domésticas por todo el mundo, causando diversos síntomas clínicos. El paramixovirus pertenece a la familia Paramyxoviridae y al Avulovirus genus que incluye nueve serotipos (APMV 1 a 9). La leucosis linfoide es una neoplasia inducida por retrovirus. Los retrovirus aviarios pertenecen a la familia Retroviridae y el género Alpharetrovirus. Los coronavirus pueden causar enfermedades respiratorias y entéricas en varias especies de aves. Ellos pertenecen a la familia Coronaviridae y a los grupos 3a y 3c. En este estudio, se describe la presencia del virus en cuatro búhos, dos lechuzas (Tyto alba) y dos búhos de orejas (Rhinoptynx clamator), rescatados de las calles arboladas de São Paulo, Brasil y enviados al Centro de Recuperación de Animales Silvestres del Parque Ecológico de Tietê, donde hubo murieron los animales. Fragmentos de pulmón, delhígado y del intestino delgado de estas aves fueron procesados para microscopía electrónica de transmisión utilizando tinción negativa (preparación rápida), inmunomicroscopía y técnicas de inmunocitoquímica. Bajo microscopía electrónica de transmisión, partículas de paramixovirus, pleomórficas, aproximadamente esféricas o filamentosas, de 100 a 500 nm de diámetro con un sobre cubierto por espigas, y nucleocápside helicoidal con características de espiga, midiendo 15 a $20 \mathrm{~nm}$ de diámetro, fueron visualizadas en las muestras de pulmón, hígado e intestino delgado de todos los búhos. En muestras de intestino delgado de dos búho de orejas (búhos 3 y 4) se detectaron partículas pleomórficas con coronavirus de un diámetro de 75-160 nm con un sobre con forma de corona solar, con proyecciones de aproximadamente $20 \mathrm{~nm}$ de diámetro. En el hígado de un búho de orejas (búho 4) se observaron partículas pleomórficas de retrovirus con un diámetro de 80-145 nm contiene pequeñas proyecciones, con un diámetro de $9 \mathrm{~nm}$. La presencia de agregados formados por la interacción antígeno-anticuerpo, caracterizó el resultado positivo que obtuvimos en la técnica de microscopía immunoelectrónica para paramixovirus, retrovirus y coronavirus. En la técnica de inmunocitoquímica, la interacción antígeno-anticuerpo fue fuertemente reforzada por las partículas de oro coloidal denso en los virus.

PALABRAS CLAVE: Paramyxovirus; Coronavirus; Retrovirus; Buhos; Microscopía electrónica de transmisión.

\section{REFERENCES}

Alexander, D. J. Newcastle disease, other avian paramyxoviruses, and pneumovirus infections. In: Diseases of poultry. Eds. Y. M. Saif, H. J. Barnes, J. R. Glisson, A. M. Fadly, L. R. McDougald \& D. E. Swayne Iowa, State Press, Ames, Iowa, 2003. pp. 63-99.

Almeida, J. D. \& Waterson A. P. The morphology on virus antibody interaction. Adv. Virus Res., 15:307-38,1969.
Beck, I.; Gerlach, H.; Burkhardt, E. \& Kaleta, E.F. Investigation fo several selected adjuvants regarding their efficacy and side for the production of a vaccine for parakeets to prevent a disease caused by a paramyxovirus type 3 . Vaccine, 21:100622,2003

Berthiaume, L.; Alain, R. M. A.; Laughlin, B.; Payment, P. \& Trepainer, P. Rapid detection of human viruses in feces by a 
simple and routine immune electron microscopy technique. $J$. Gen. Virol., 55:223-27, 1981.

Brenner, S. \& Horne, R. W. A negative staining method for high resolution electron microscopy of viruses. Biochem. Biophys. Acta., 34:103, 1959.

Breslin, J. J.; Smith, L.G.; Fuller, F. J. \& Guy, J. S. Sequence analysis of the turkey coronavírus nucleocápside gene and 3' untraslated regionidentifies the virus as a close relative of infectious bronchitis virus. Virus Res., 65:187-98, 1999.

Catroxo, M. H. B.; Ito, N. M. K.; Miranda, L. B.; Miyaje, C. I.; Cappellaro, C. E. M. P. D. M.; Andrade, P. C. M. \& Sanchez, M. E. Presença de partículas semelhantes a coronavírus em fezes de emas (Rhea americana) com diarréia. Arq. Inst. Biol., 63:24, 1996.

Catroxo, M. H. B.; Silva, J. C. R.; Menezes, A. C.; Curi, N. A. \& Schmich, H. Presença de partículas semelhantes a corona e paramixovírus em fezes de aves silvestres (Passeriformes e Psittaciformes). A Ornitologia no Brasil - Pesquisa Atual e Perspectivas, 1:161-9, 2000.

Catroxo, M. H. B. Cinomose Canina. O Biológico, 65(1):1-2, 2003.

Catroxo, M. H. B.; Martins, A. M. C. R. P. F.; Macruz, R.; Pongiluppi, T.; Petrella, S. \& Gabriel, C. P. Detecção de retrovírus e paramixovírus em fragmentos de órgãos de sabiás (Turdus leucomelas e Turdus rufiventris). In: XIV Congresso Brasileiro de Ornitologia, Ouro Preto, M.G., 2006.

Catroxo, M. H. B.; Pongiluppi T.; Melo, N. A.; Milanelo, L.; Petrella, S.; Martins, A. M. C. P. F. \& Rebouças, M. M. Identification of poxvirus under transmission electron microscopy during outbreak period in wild birds, in São Paulo, Brazil. Int. J. Morphol., 27(2):577-85, 2009.

Cavanagh, D. \& Naqi, S. Infectious bronchitis. In: Diseases of poultry. Eds. B. W. Calnek; H.J. Barnes, C. W. Beard, L. R. McDougald, Y. M. Saif. ed. Ames, IA: Iowa State University Press, Iowa State, 1997. pp.511-26.

Chang, P. C.; Hsieh, M. L.; Shien, J. H.; Graham, D. A.; Lee, M. S. \& Shied, H. K. Complete nucleotide sequence of avian paramyxovirus type 6 isolated from ducks. J. Gen. Virol., 82:215768, 2001.

Choi, K. S.; Lee, E. K.; Jeon, W. J.; Nah, J. J.; Kim, Y. J.; Lee, M. Y.; Lee, H. \& Kwon, J. H. Isolation of a recent Korean epizootic strain of Newcastle disease virus from Eurasian scops owls affected with severe diarrhea. J. Wildl. Dis., 44(1):193-8, 2008.

Circella, E.; Camarda, A.; Martella, V.; Bruni, G.; Lavazza, A. \& Buonavoglia, C. Coronavirus associated with an enteric syndrome on a quail farm. Avian Pathol., 36(3):251-8, 2007.

Coffin, J. M. Structure and classification of retroviruses. In: The Retroviridae. Ed. J.A. Levy. Plenum Press, New York, 1992. v.1, pp. 19-49.
Dea, S. \& Tijssen, P. Antigenic and polypeptide structure of turkey enteric coronaviruses as defined by monoclonal antibodies. $J$. Gen. Virol., 70:1725-41, 1989.

Dea, S.; Verbeek, A. J. \& Tyssen, P. Antigenic and genomic relationships among turkey and bovine enteric coronaviruses. $J$. Virol., 64:3112-8, 1990.

Dea, S. \& Garzon, S. Identification of coronaviruses by the use of indirect protein A-gold immunoelectron microscopy. J. Vet. Diagn. Invest., 3:297-305, 1991.

Derrick, K.S. Quantitative assay for plant viruses using serologically specific electron microscopy. Virol., 56:652-653, 1973.

Fadly, A. M. Avian retroviruses. Veterinary Clinics of North America. Food Animal Practice, 13(1):71-85, 1997.

Fenner, F., Bachmann, P. A.; Gibbs, E. P. J.; Murphy, F. A.; Studdert, M. J. \& White, D. O. Virología Veterinaria. Zaragoza, Acribia, 1992.

Fischer, N.; Krach, U.; Niebert, M. \& Tonjes, R. R. Detection of porcine endogenous retrovirus (PERV) using highly specific antisera against Gag and Env. Virol., 311(1):222-8, 2003.

Fowler, M. E. Infectious and zoonotic diseases. In: Zoo \& Wild Animal Medicine. Ed. M.E. Fowler. W. B. Saunders, Philadelphia. 2 ed. 1986. pp.494-7.

Goff, S. P. Retroviridae: The Retroviruses and Their Replication. In: Fields Virology. $5^{\text {a }}$ ed. Eds. D. M. Knipe, P.M. Howley, P. M. Philadelphia, Lippincott Williams and Wilkins, 2007. v. 2, p. 1999-2069.

Gohm, D.; Schelling, E.; Audigé, L. \& Thur, B. Newcastle-Krankheit - seroeoidemiologische untersuchung einer hochansteckenden tierseuche beim geflügel und bei wild-vögeln in der schweiz. Schweiz. Arch. Tierheilk., 141:549-58, 1999.

Gough, R. E. \& Alexander, D. J. Isolation and preliminarycharacterization of a paramyxovirus from collared doves (Streptopeliam decaocto). Avian Pathol., 12:125-34, 1983.

Gough, R. E.; Manvell R. J.; Drury, S. E.; Naylor, P. F.; Spackman, D. \& Cooke, S.W. Deaths in budgerigars associated with a paramyxovirus-like agent. Vet. Rec., 133(5):123, 1993.

Gough, R. E.; Cox, W. J.; Winkler, C. E.; Sharp, M. W. \& Spackman, D. Isolation and identification of infectious bronchitis virus from pheasants. Vet. Rec., 38:208-9, 1996.

Gough, R. E.; Drury, S. E.; Culver, F.; Britton, P. \& Cavanagh, D. Isolation of a coronavirus from a green-cheeked Amazon parrot (Amazon viridigenalis cassin). Avian Pathol., 35(2):122-6, 2006.

Greenacre, C. B. Viral diseases of companion birds. Vet. Clin. Exot. Anim., 8:85-105, 2005. 
Grund, C. H.; Werner, O.; Gelderblom, H. R.; Grimm, F. \& Kosters, J. Avian Paramyxovirus serotype 1 isolates from the spinal cord of parrots display a very low virulence. J. Vet. Med. B., 49:445-51, 2002.

Guy, J. S.; Barnes, H. J.; Smith, L. G. \& Breslin, J. Antigenic characterization of a turkey coronavirus identified in poultry enteritis and mortality syndrome-affected turkeys. Avian Dis., 41(3):583-90, 1997.

Harris, J. R.; Bhella, D. \& Adrian, M. Recent developments in negative staining for transmission electron microscopy. Microsc. Microanal., 20:5-9, 2006.

Harrison, G. I. \& Harrison, L. R. Disorders of the integument. In: Clinical Avian Medicine and Surgery. 1986.

Hatai, H.; Ochiai, K.; Murakami, M.; Imanishi, S.; Tomioka, Y.; Toyoda, T.; Ohashi, K. \& Umemura, T. Prevalence of fowl glioma-inducing virus in chickens of zoological gardens in Japan and nucleotide variation in the env gene. J. Vet. Med. Sci., 70(5):469-74, 2008.

Hayat, M. A. \& Miller, S. E. Negative Staining. Mc. Graw-Hill Publ. Company., 1990. 235p.

Hazelton, P. R. \& Gelderblom, H. R. Electron microscopy for rapid diagnosis of emerging infectious agents. Emerg. Infect. Dis., 9(3):294-303, 2003.

Hoffle, U.; Blanco, J. M. \& Kaleta, E.V. Seroprevalence of avian paramyxovirus 1,2 and 3 in captive and free-living birds of preys in Spain (preliminary results): implications for management of wild and captive populations. Ann. N.Y. Acad. Sci. 969:213-6, 2002.

Hughes, L. A.; Savage, C.; Naylor, C.; Bennett, M.; Chantrey, J. \& Jones, R. Genetically diverse coronaviruses in wild bird populations of northern England. Emerg. Infect. Dis., 15:10914, 2009.

Jonassen, C. M.; Kofstad, T.; Larsen, I. L.; Lovland, A., Handeland, K.; Follestad, A. \& Lillehaug, A. Molecular identification and characterization of novel coronaviruses infecting graylag geese (Anser anser), feral pigeons (Columbia livia) and mallards (Anas platyrhynchos). J. Gen. Virol., 86:1597-607, 2005.

Jorgensen, P. H.; Herczeg, J.; Lomniczi, B.; Manvell, R. J.; Holm, E. \& Alexander, D. J. Isolation and characterization of avian paramyxovirus type 1 (Newcastle disease) viruses from a flock of ostriches (Struthio camelus) and emus (Dromaius novaehollandiae) in Europe with inconsistent serology. Avian Pathol., 27:352-8, 1998.

Jung, A.; Grund, C.; Muller, I. \& Rautenschlein, S. Avian paramyxovirus serotype 3 infection in Neopsephotus, Cyanoramphus, and Neophema species. J. Avian. Med. Surg., 23:205-8, 2009.
Kaleta, E. F. \& Baldhauf, C. Newcastle disease in free-living and pet birds. In: Newcastle disease. Eds. D. J. Alexander, Kluwer Academic, Boston, MA. 1988. pp. 197-246.

Knutton, S. Electron microscopical methods in adhesion. Meth. Enzymol., 253:145-58, 1995.

Kou, Y. T.; Chueh, L. L. \& Wang, C. H. Restriction Fragment Length Polymorphism Analysis of the F Gene of Newcastle Disease Viruses Isolated from Chickens and an Owl in Taiwan. J. Vet. Med. Sci., 61:1191-5, 1999.

Lamb, R. \& Parks, G. Paramyxoviridae: the viruses and their replication. In: Knipe DM, Howley PM, Griffin DE, Lamb RA, Martin MA, Roizman B, Straus SE, eds. Philadelphia: Lippincott Williams \& Wilkins. 2007. pp 1449-96.

Leeuw, O. \& Peeters, B. Complete nucleotide sequence of Newcastle disease virus: evidence for the existence of a new genus within the subfamily Paramyxovirinae. J. Gen. Virol., 80:131-6, 1999.

Liu, S.; Chen, J.; Kong, X.; Shao, Y.; Han, Z.; Feng, L.; Cai, X.; Gu, S. \& Liu, M. Isolation of avian infectious bronchitis coronavirus from domestic peafowl (Pavo cristatus) and teal (Anas). J. Gen. Virol., 86:719-25, 2005.

Loupal, G. Leukosen bei zoo- und wildvögeln. Avian Pathol., 3(4):703-14, 1984.

Madeley, C. R. Electron microscopy and virus diagnosis. J. Clin. Pathol., 50:454-6, 1997.

Martins, A. M. C. R. P. F.; Catroxo, M. H. B.; Leme, M. C. M. \& Portugal, M. A. S. Leucose linfóide em canários (Serinus canarius - Linn, 1748). Arq. Inst. Biol., 71(4):503-506, 2004.

Martins, A. M. C. R. P. F. \& Catroxo, M.H.B. Vírus oncogênicos em animais. O Biológico, 71(1):21-27, 2009.

Motta-Júnior, J.C.; Alho, C.J.R. Ecologia alimentar de Athene cunicularia e Tyto alba (Aves: Strigiformes) nas Estações Ecológica de Jataí e Experimental de Luiz Antônio, SP. Estação Ecológica de Jataí, 1:346, 2000.

Mustaffa-Babjee, A.; Spradbrow, P. B. \& Samuel, J.L. A pathogenic paramyxovirus from a budgerigar (Melopsittacus undulatus). Avian Dis., 18:226-30, 1974.

Nerome, K.; Nakayama, M.; Ishida, M. \& Fukumi, H. Isolation of a new avian paramyxovirus from budgerigar (Melopsittacus undulatus). J. Gen. Virol., 38:293-301, 1978.

Nobel, T. A. Avian leukosis (lymphoid) in an egret (Egretta alba). Avian Pathol., 1(1):75-6, 1972.

OIE. Manual of Diagnostic Tests \& Vaccines for Terrestrial Animal. In: Avian Infectious Bronchitis. 6 ${ }^{\mathrm{a}}$. Ed. France, Paris, 2008. pp. 443-55. 
Oliveira Júnior, J. G.; Portz, C.; Loureiro, B. O.; Schiavo, P. A.; Fedullo, L. P. L.; Mazur, C. \& Andrade, C. M. Vírus da doença de Newcastle em aves não vacinadas no Estado do Rio de Janeiro. Cienc. Rural, 33(2):381-3, 2003.

Palmer, G. H. \& Stauber, E. Visceral lymphoblastic leukosis in an African grey parrot. Vet. Med. Small Anim. Clinician, 76(9):1355, 1981.

Pennycott, T. W. Causes of mortality and culling in adult pheasants. Vet. Rec., 146:2738, 2000.

Pohuang, T.; Chansiripornchai, N.; Tawatsin, A.; Sasipreeyajan, J. Detection and molecular characterization of infectious bronchitis virus isolated from recent outbreaks in broiler flocks in Thailand. J. Vet. Sci., 10(3):219-23, 2009.

Pongiluppi, T.; Catroxo, M. H. B.; Godoy, S. N.; Milanelo, L.; Ferreira, J. P. N.; Curi, N. A. \& Petrella, S. Detecção de partículas semelhantes a coronavírus em fezes de Falcão-peregrino (Falco peregrinus) por microscopia eletrônica de transmissão. In: $2^{\circ}$ Congresso de Iniciação Científica em Ciências Agrárias, Biológicas e Ornamentais, São Paulo, SP., 2004.

Pongiluppi, T.; Catroxo, M. H. B.; Bersano, J. G. \& Petrella, S. Detecção de retrovírus em nódulos de moela de rolinha-caldode-feijão (Columbina talpacoti) por microscopia eletrônica de transmissão. O Biológico, 68(2):156-9, 2006.

Ritchie, B. W. \& Carter, K. Avian viruses: Function and control. Lake Worth, Florida, Ed. Publishing Incorporated, 1995.

Ritchie, B. W.; Harrison, G. J. \& Harrison, L. R. Avian Medicine: Principles and application. Florida, Ed. Wingers Publishing Inc., 1994. pp.865-74.

Sander, O. Untersuchungen uber die herpesvirusinfektion der Greifvo gel (Falconiformes und Accipitriformes) sowie vergleichende Studien an 5 Isolaten aus verschiedenen Greifvo" - geln. Veterinary Medicine Dissertation, University of Gießen, Gießen, Germany, 1995. 92 pp.

Schettler, E.; Fickel, J.; Hotzel, H.; Sachse, K.; Streich, W. J.; Wittstatt, U. \& Frolich, K. Newcastle disease virus and Chlamydiapsittaci in free-living raptors from Eastern Germany. J. wildl Dis., 39(1):57-63, 2003.

Sick, H. Ornitologia Brasileira. Ed. Nova Fronteira. São Paulo, 393405, 1997.

Shihmanter, E.; Weisman, Y.; Lublin, A.; Mahani, S. \& Panshin, A.; Lipkind, M. Isolation of avian serotype 3 paramyxoviruses from imported caged birds in Israel. Avian Dis., 42:829-31, 1998.

Shin, H. J.; Njenga, M. K.; McComb, B.; Halvorson, D. A.; Nagaraja, K.V. Avian pneumovirus (APV) RNA from wild and sentinel birds in the United States has genetic homology with RNA from APV isolates from domestic turkeys. J. Clin. Microbial., 38(11):42824, 2000 .
Sousa, E.; Werther, K. \& Berchieri Júnior, A. Assessment of Newcastle and infectious bronquitis pathogens, and Salmonella spp. In wild birds captured near poultry facilities. Arq. Bras. Med. Vet. Zootec., 62(1):219-23, 2010.

Telbis, C.; Newmann, U.; Heffels-Redmann, U.; Glunder, G.; Friederichs, M.; Lister, S. A.; Alexander, D. J. \& Siegmann, O. Comparative studies of paramyxovirus isolates from wild birds. Zentralbl Veterinarmed B., 36(4):279-91, 1989.

Valicek, L.; Smid, B. \& Machatkova, M. Electron microscopy ob bovine leukosis viruses (BLV) in a fetal lamb spleen cell line. Vet. Med.(Praha). 30(1):37-44, 1985.

Van Regenmortel, M. H. V.; Fauquet, C. M.; Bishop, D. H.; Carstens, E. B.; Estes, M. K.; Lemon, S. M.; Maniloff, J.; Mayo, M. A.; Mcgeoch, D. J.; Pringle, C. R. \& Wickner, R. B. In: VII Report of the International Committee on Taxonomy of Viruses. San Diego. Procedings. San Diego: Academic Press, 2000. 1167 p.

Varejka, F. \& Tomsik, F. The role of house sparrow (Passer domesticus L.) in the spread of leukosis viruses in poultry. I. Determination of neutralizing antibodies. Acta Vet. Brno., 43(4):367-70, 1974.

Wadsworth, P. F.; Jones, D. M. \& Pugsley, S. L. Some cases of lymphoid leukosis in captive wild birds. Avian Pathol., 10(4):499504, 1981.

Woo, P. C.Y.; Lau, S .K. P.; Lam, C. S. F.; Lai, K. K. Y.; Huang, Y.; Lee, P.; Luk, G. S. M.; Martingil, K. C.; Chan, K. H. \& Yuen, K.Y. Comparative analysis of complete genome sequences of three avian coronaviruses reveals a novel group $3 \mathrm{c}$ coronavirus. J. Virol., 83:908-17, 2008.

Woo, P. C. Y.; Lau, S. K. P.; Huang, Y. \& Yuen, K-Y. Coronavirus diversity, phylogeny and interspecies jumping. Exp. Biol. Med. (Maywood)., 234(10):1117-27, 2009.

Worthington, K. J.; Currie, R. J. \& Jones, R.C. A reverse transcriptase-polymerase chain reaction survey of infectious bronchitis virus genotypes in Western Europe from 2002 to 2006. Avian Pathol., 37:247-57, 2008.

Zhang, G. O.; Zhao, J. X.; Wang, H. W.; Yang, A. M.; Bu, C. Y. \& Wang, M. Isolation, identification, and comparison of four isolates of avian paramyxovirus serotype 2 in China. Avian Dis., 50(3):386-90, 2006.

Correspondence to:

Prof. Dr. Marcia Catroxo

Electron Microscopy Laboratory

Research and Development Center in Animal Health

Biological Institute of São Paulo

Av. Conselheiro Rodrigues Alves, 1252

CEP 04014-002

Vila Mariana, São Paulo, SP

BRAZIL

Received: 11-03-2010

Accepted: 04-04-2010

Email: catroxo@biologico.sp.gov.br 